appeared since the last edition that revision has practically amounted to rewriting. It is, of course, impossible in a small book of this kind to give anything like a com. plete account of the analysis of all the substances dealt with, which include most ordinary articles of food, some drugs, soaps, disinfectants, and urine; but good judgement has been shown in selecting the essential matters to be included under each heading, and a very useful little work is the result. We have not found any section in which the information is not fairly abreast of current knowledge.

\section{NOTES ON HEALTH RESORTS.}

\section{VERNET-LES.BAINS, PYRENĖES ORIENTALES.}

$$
\text { By G. H. Brandt, M.D. }
$$

I HAVE had the good fortune during my autumn holiday of visiting a most interesting part of France, that which lies at the extreme south and eastern part of the department of the Pyrenées Orientales bordering on the Spanish frontier. Vernet, the most southern of the winter resorts of France, is situated in a winding valley at an altitude of over $2,000 \mathrm{ft}$. in the midst of a circle of mountains, and sheltered from the Roussillon winds by the Canigou, $9,000 \mathrm{ft}$. high.

The Romans have left traces of their passage, and in the twelfth century the Abbots of St. Martin du Canigou had at Vernet a small thermal bathing-place: Since that remote epoch Vernet, with its numerous thermal sulphurous springs, owing, no doubt, to its proximity to the celebrated medical school of Montpellier, gradually developed, but it is only within the last few years that the late Count Henry de Burnay took it up, and by his intelligent outlay made it one of the most luxurious spas in France.

If we consider its altitude, its sheltered position amongst mountains covered with pine forests, its sunny aspect and dry atmosphere, one may claim for it the title of a tem. perate climate in summer and a mild and reposeful climate in winter. Snow and frost are rare.

Vernet possesses twelre springs of mineral water, varying in temperature from $47^{\circ} \mathrm{F}$. to $150^{\circ} \mathrm{F}$. The waters are unctuous to the touch and almost inodorous; the taste is not disagreeable. All the twelve springs agree in being sulphurous and alkaline; one is also ferruginous.

The climatic conditions and waters of Vernet are especially serviceable in cases of rheumatic arthritis and of chronic rheumatism, nervous and general weakness, and in caitarrhal affections of the respiratory tract.

At Vernet-les-Bains there are, in a well laid-out and finely-timbered park, beautiful hotels; furnished villas and flats, with all the comforts that modern science has devised-perfect drainage and abundance of pure spring potable water, central heating, electricity, lifts, etc. A dairy is attached to the establishment, with healthy cows. Excellent walks, fishing, and shooting can be found in the neighbourhood. Picnics, excursions, dances, and musical entertainments frequently take place during the season. A library of French and English books is maintained by the establishment; and games, both indoor and outdoor, are provided.

During the last ten years there have been per annum 37 wet days, 44 cloudy, 121 with some clouds, and 163 without clouds. The sudden change of temperature and the damp and chilly sensations felt on the Riviera do not occur, a fact which may, I believe, be accounted for by the dry, porous granite soil with a dry atmosphere and the absence of wind and fog at an altitude of over 2,000 feet.

The vine, the fig, the olive, the pomegranate, the clematis, the zeutique of Algeria and the Grecian Isles, the oleander as well, and many other plants from Italy, Malta, and Algeria, with a variety of palms, thrive, and the delicate mimosas are in blossom almost all the winter in the Alzina Gardens.

Vernet-les-Bains is not an expensive place, and is easily got at by through carriage from Paris (Quai d'Orsay). The managers have made arrangements to suit all purses, giving most excellent and comfortable accommodation with the best food, and are always ready to supply full information to all inquirers.

\section{MEDICAL ORGANIZATION IN CASE OF INVASION.}

\section{ENGLAND AND WALES.}

The Secretary of State for War issued on August 16th to secretaries of Territorial County Associations in England and Wales a Scheme for the Organization of Voluntary Aid for sick and wounded in the event of war in the home territory.

The scheme proposes to make use of the existing organization of the British Red Cross Society and to develop it on a large scale, so that it shall comprehend every district in England and Wales. The help of the St. John Ambulance has also been secured for the training of detachments. A county system has been adopted because it is that upon which both the Territorial Force and the British Red Cross Society are organized.

Each County Association is charged with the responsibility of organizing voluntary aid in the county, and is required, through the local branches of the British Red Cross Society, to form Voluntary Aid Detachments. There need be no limit to the number of such detachments, but those in each county would be under the command of a County Director.

The whole organization is intended to provide supplementary aid to the Territorial Medical Service to meet the needs of war at home, and is modelled to a large extent on the Japanese system, a memorandum on which by Lieutenant-Colonel W. G. Macpherson, C.M.G., R.A.M.C., is given in an appendix to the scheme. In another appendix is given a sketch of the existing military organization of the Territorial Force, which it will be useful to reproduce in full :

\section{Existing Organization of the Territorial Medical} SrRvice.

"The medical service of the Territorial Force is modelled on that of the Expeditionary Force of the army, with the essential difference that it is organized for active service in home territory only. Its ranks include all that highlytrained personnel which is necessary for the preservation of the health of troops in the field and for the professional treatment and care of the sick and wounded. Being an integral part of the medical service of the army as a whole, its technical training is in the hands of the DirectorGeneral, Army Medical Service, assisted by his represen. tatives, the Administrative Medical Officers of Territorial Divisions; these latter being themselves Territorial Officers, who are each allowed a retired officer of the regular Royal Army Medical Corps to assist him.

"To give expert advice on sanitary matters, and to assist the Administrative Medical Officers in the preven tion of disease, officers who, from the nature of their civil duties, have special knowledge of the science of public health and sanitation, are appointed to the head quarters of each Territorial Division. In addition, over 100 sanitarian and medical officers of health throughout the United Kingdom have been given commissions and will be available in war for duty as sanitary officers with the Territorial Force within their own areas.

"In the Expeditionary Force each battalion has one officer, one corporal, and four privates Royal Army Medical Corps, attached to it. In addition to this medical establishment in the Territorial Force, a battalion has an extra medical officer. This-the only difference in the organization of the Territorial medical service with combatant units - is in order that by arrangement between two medical officers, the requirements of their practices may not be unduly interfered with in time of peace by their military duties. The medical officers examine the recruits of their battalion, train the regimental stretcher-bearers and men for sanitary duties, and supervise the duties of the Royal Army Medical Corps attached. In camp and in the field, the medical officer with the battalion is assisted in the prevention of disease by the Royal Army Medical Corps rank and file attached, whose special duty it is to purify the drinking water, and who also assist him in carrying out the work of disinfection as well as his duties towards the sick. The battalion provides him with a lance-corporal and a private, the latter to 